\title{
Geomorphic Classification and Assessment of Mangrove Degradation in the Henry's and Patibania Island, South Western Sundarban
}

\author{
Debasmrity Mukherjee ${ }^{1 *}$, Ashis Kumar Paul ${ }^{2}$ \\ ${ }^{1}$ Research Scholar, Dept. of Geography \& Environment Management, Vidyasagar University, Midnapore, India \\ ${ }^{2}$ Professor, Department of Geography \& Environment Management, Vidyasagar University, Midnapore, India \\ *Corresponding author: debasmrity4email@gmail.com
}

\begin{abstract}
The coast of Henry's island, extending from Saptamukhi River in the east to Bakkhali River in the West. In the hot and humid climate of the Sundarban, a negligible input of fresh water through tidal creeks, high evaporation rate at the surface area are the probable reasons behind the evolution of Hypersaline patches of Henry's and Patibunia Island. The dense salt patches develop in the abandoned portion of the surface then sinks and move out of the tidal estuaries as subterranean flow or a bottom current to make the environment more saline. Development of Saltpan is one of the major hindrances for the growth of mangroves and hampers the ecological balance of Sundarban. Present paper attempts to highlight- I) To study and identification of Geomorphological settings of both island. ii) Analysis of Physico-chemical properties of hyper saline soil. iii) Identification of hyper-saline patches and their impact on mangrove degradation. Application of remote sensing technique and GIS analysis help to find out the relationship between mangrove degradation and salinity within the islands area in the last few decades. Development of hyper saline patches and changing environmental parameters are how much responsible for the mangrove degeneration process are major issues of this paper. The Forest Department has attempted to restore the growth of mangrove and improve fragile ecosystem but without understanding the geomorphology and environmental condition, it is not possible to implement proper managemental strategies for wetland restoration process.
\end{abstract}

Keywords: Hypersaline, Physico-chemical, Restore, Saltpan, Subterranean.

\section{Introduction}

The Sundarban has always been considered to be a dynamic region. The changes in this region have mainly been caused by the fluvial activities. The rapid transformation in the landscape of delta is evident in the last couple of centuries which are founded in topographical maps and satellite imageries. The monsoonal dynamics causing rains and flood have been playing major changes in the landscape development in the delta.

The Indian Sundarbans, at the apex of Bay of Bengal (between $21^{\circ} 31^{\prime} \mathrm{N}$ and $22^{\circ} 40^{\prime} \mathrm{N}$ latitude and $88^{\circ} 03^{\prime} \mathrm{E}$ and $89^{\circ} 07^{\prime} \mathrm{E}$ longitude) is located on the southern triangle of West Bengal, on the North - East Coast of India. It covers an area of 9630sq.km which is bounded in the North by an imaginary line called Dampier - Hodges lines, the South by Bay of Bengal, the east by Icchamati - Kalindi - Raimangal rivers and in the west by Hoogly. It falls within two districts of 24 Parganas (North and South), in the state of West Bengal and consist of an expanse of low flat islands and mud bank separated by a network of anastomosing tidal channels and rivers. Presently the rivers in the western parts (Hoogly and Muriganga) are connected to the Himalayan glaciers through Ganges originating at the Gangotri glaciers; whereas the five eastern sector's rivers like Saptamukhi, Thakuran, Matla, Gosaba, and Harinbhanga are all tidally fed.

\section{A. Study Area}

Henry Island is located in between the slope of Bay of Bengal and Saptamukhi river estuary. The island is very much popular for its fishery project and mangrove ecotourism and fish drying platform. Geomorphologically Sundarban can be classified as a coastal plain estuary. Major land forms observed are mangrove swamp, mudflats, hyper saline, creeks, salt flats, salt ponds etc. tidal mudflats help to develop mangrove species and provide suitable environment for colorization of mangrove. Mangrove forest and its zonation patterns richness, around the fisheries project is seen from the watch tower from ecotourism complex. Shoreline erosion development of hyper saline tract within mangrove, tidal drainage loss is very much evident on the island since decade. Large areas of mangrove forest are degraded for the extent of human settlement since 1970's. Mangroves were also lost due to Westover sand deposits in the inner part of shore front erosion. On the other hand, Patibunia Island is a part of reserve forest and no-man's land extending from the SouthWest Fresarganj - Patibunia creeks. The main characteristics of this island are dwarfed mangroves which are found in the inner part due to drainage loss and development of hyper-saline tract. Rich forests are seen along the tidal creek and active tidal flat.

The lower delta region is very sensitive and take active role in maintain balance of hydrodynamics between riverine input and salt water intrusion. The present study only concentrate on Henry and Patibunia islands of Sundarban. The coast of Henry island and Patibunia island are extending from Saptamukhi 
river in the east to Bakkhali river in the west. This island is part of meso and macro tidal environment. There was dense forest area in (S0I toposheet No 79C) scale of 1:250,000 (1975). In recent years several studies have been conducted on Sundarban's mangroves based on remotely sensed data to detect the pattern of geomorphological change, to show the climatic vagaries and hypersaline condition heralded the growth of mangrove mainly in Southwestern Indian Sundarban. Side specific or micro level studies has been done to get the idea of landscape transformation and consequent changes in vegetative dynamics. Hence, in this study, an attempt has been made to assess to make the changes and classify geographic settings and mangrove degradation in Henry and Patibunia Island. The objectives were to examine the dynamics of landscape change and suggest some guideline towards better management of these vulnerable coastal wetlands.

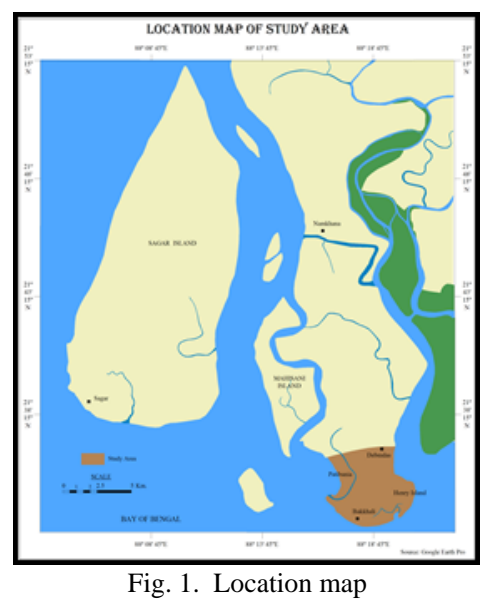

\section{Objectives}

- Classifications of geomorphic settings of islands.

- Analysis of physico - chemical properties of soils.

- Identification of hyper-saline patches and their impact on mangrove degradation

\section{Materials and Methods}

In the last 150 years intense human intervention and natural calamities have been passing an increasing threat to the existence of Sundarban as evident from the continual loss of significant amount of mangrove degradation. For the present study of Henry Island and Patibunia Island have been chosen to identify the hyper saline patches and its impacts of mangrove degradation. The total work has been carried out in three ways,

1. Pre field study

2. Field study

3. Post field study

During Pre-field study, satellite images were downloaded from USGS platform from $18^{\text {th }}$ century to $20^{\text {th }}$ century and toposheet have been consulted; block level administrative maps were collected. During the field survey, soil samples were taken from Hyper-saline tracts for analysis of physical and chemical properties wash over sand fan lobes as well as exposed consolidated mud banks were identified for analysis. soil pits were constructed in the saltpan tracts for sediment sampling. GPS survey, Photographic documentations also being made as for future reference. Total station survey was conducted in some parts of Islands. In post field study soil sample data has been analyzed and maps, diagrams, cartographic representations have been prepared.

\section{Result and Discussions}

Mangrove forest of Sundarban is World's largest halophytic formation. These are most opportunistic plant to find out suitable environment, coastal process over time and space. They act as natural buffer against the tidal waves and coastal erosion. At present mangroves of Sundarbans are affected by multiple ways of degradation that will produce significant vulnerabilities and risk to the inhabitants of Sundarban.

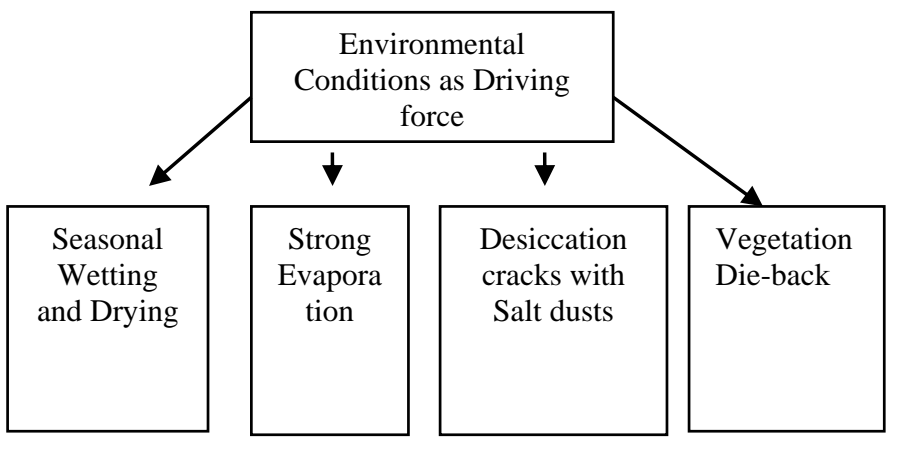

Fig. 2. Environmental conditions as driving force

From the temporal field observation and remote sensing study it has been explored and reveled that a significant amount of mangrove forest lost incurred in 2016. Expansion of Hypersaline patches, storm effect and sediment deposition parameters are mainly responsible for mangrove degradation in Patibunia Island. Moreover, fisheries development, tourism industry land erosion, hyper-salinity, and sediment depositions we sequentially responsible for mangrove degradation in Henry island. Apart from these Seasonal wetting and drying, high evaporation rate help to develop desiccation cracks on the surface which indirectly affect the mangrove vegetation dieback process. Changing environmental parameters

\section{A. Geomorphological Settings of Islands}

In this paper to assess the mangrove forest dynamics as well as its degradation process the islands have been categorized into several geomorphological units with the help of supervised classification technique of remote sensing process. This region has been affected by infrequent tidal inundation due to configuration of the islands and uneven distribution of sediments in the depositional environment. Submergence of certain portion of mangroves and active tidal flat increases salinity level of the soil and hinder the growth and survival of mangroves species. Salinity level, tidal inundation frequency 
and moreover coastal configuration are the basis of geomorphological settings of the islands.
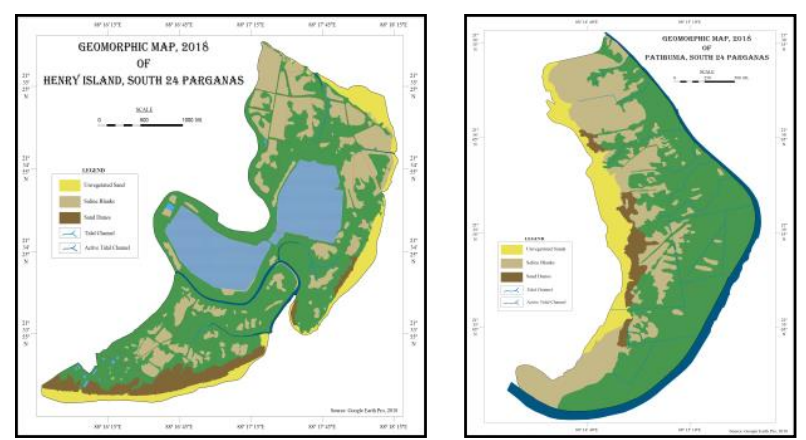

Fig. 2. Geomorphological Map of Henry's and Patibania Island

Unvegetated sand covers, active tidal channel, sand dunes, saline blanks, tidal mud flats, salt marshes are the major classification of geomorphic settings. Maximum areas of Sundarban is of swampy forests. Salt pan which is basically salt encrusted area with a cover of sparse vegetation found within the mangrove areas mostly. Highly salt affected flat surface with the remains of dead stumps dwarfed mangroves are dominant one in Patibunia and Henrys Islands. Saline blanks covered by algae are visible in the central portion of islands. Seasonal rain water supply, salt water intrusions, wash over deposits takes vital role in the degradation of mangroves and the formation of hyper saline patches. Mangroves characteristics are different in different areas of islands.

\section{B. Analysis of physico-chemical properties of different micro zonation map of the island}

To analyze the physical and chemical properties of the soil, several soil samples were collected from different parts of Henry and Patibunia islands specifically in hypersaline areas. For easy sampling, Hypersaline patches are divided into different segment like fringe area, outer area, central area etc. These zones are having different mangrove species along the various salinity levels. For example, fringe area having high vegetation species, whereas inner area having comparatively moderate species colonization. Central area of the hypersaline zone is having dwarf mangrove vegetation indicating retarded growth and finally core area is completely absence of vegetation., The given table showing the glimpses of some data of certain parameters like $\mathrm{pH}$, moisture content, salinity and organic matter which clearly indicating the presence of animal and plant richness in outer periphery and low organic content in central portion.

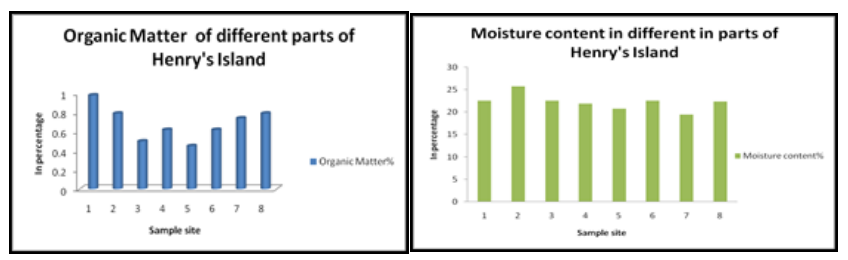

Fig. 3. Organic matter and moisture content of soil (Henry's Island)
Table 1

Characteristics of soil in Henry's Island

\begin{tabular}{|l|l|l|l|l|l|}
\hline $\begin{array}{c}\text { No. of } \\
\text { Sample }\end{array}$ & $\begin{array}{c}\text { GPS } \\
\text { Points }\end{array}$ & $\begin{array}{c}\mathrm{pH} \\
1: 5 \\
\text { ratio }\end{array}$ & $\begin{array}{c}\text { Moisture } \\
\text { Content } \\
\%\end{array}$ & $\begin{array}{c}\text { Salinity } \\
\text { P.p.t }\end{array}$ & $\begin{array}{c}\text { Organic } \\
\text { matter } \\
\%\end{array}$ \\
\hline Sample-1 & $\begin{array}{l}21^{\circ} 34^{\prime} 37 \\
88^{\circ} 17^{\prime} 73\end{array}$ & 7.05 & 22.6 & 14.8 & 0.98 \\
\hline Sample-2 & $\begin{array}{l}21^{\circ} 34^{\prime} 38 \\
88^{\circ} 17^{\prime} 73\end{array}$ & 6.46 & 25.8 & 15.5 & 0.79 \\
\hline Sample-3 & $\begin{array}{l}21^{\circ} 34^{\prime} 45 \\
88^{\circ} 17^{\prime} 70\end{array}$ & 6.83 & 22.6 & 13.2 & 0.5 \\
\hline Sample-4 & $\begin{array}{l}21^{\circ} 34^{\prime} 41 \\
88^{\circ} 17^{\prime} 66\end{array}$ & 7.41 & 21.9 & 15.4 & 0.62 \\
\hline Sample-5 & $\begin{array}{l}21^{\circ} 34^{\prime} 41 \\
88^{\circ} 17^{\prime} 63\end{array}$ & 7.02 & 20.8 & 11.1 & 0.45 \\
\hline Sample-6 & $\begin{array}{l}21^{\circ} 34^{\prime} 41 \\
88^{\circ} 17^{\prime} 58\end{array}$ & 6.91 & 22.6 & 12.6 & 0.62 \\
\hline Sample-7 & $\begin{array}{l}21^{\circ} 34^{\prime} 38 \\
88^{\circ} 17^{\prime} 61\end{array}$ & 6.99 & 19.5 & 8.77 & 0.74 \\
\hline Sample-8 & $\begin{array}{l}21^{\circ} 34^{\prime} 38 \\
88^{\circ} 17^{\prime} 63\end{array}$ & 6.72 & 22.4 & 9.67 & 0.79 \\
\hline
\end{tabular}

Source: Field Survey

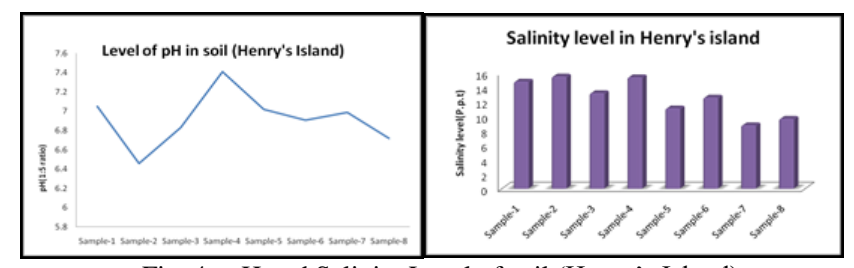

Fig. 4. pH and Salinity Level of soil (Henry's Island)

To get the salinity level and overall scenario of physical and chemical characteristics of soil, several sample were collected from different spot of Patibunia Island. The total number of samples were five those were collected along the transect where species of mangrove as well as sediment sampling had done altogether. The following table is showing the soil data sheet of Patibunia Island.

Table 2

Characteristics of soil in Patibania Island

\begin{tabular}{|c|c|c|c|c|c|}
\hline $\begin{array}{c}\text { No. of } \\
\text { Sample }\end{array}$ & $\begin{array}{c}\text { GPS } \\
\text { Points }\end{array}$ & $\begin{array}{c}\mathrm{P}_{\mathrm{h}} \\
1: 5 \\
\text { ratio }\end{array}$ & $\begin{array}{c}\text { Moisture } \\
\text { Content } \\
\%\end{array}$ & $\begin{array}{c}\text { Salinity } \\
\text { P.p.t }\end{array}$ & $\begin{array}{c}\text { Organic } \\
\text { matter } \\
\%\end{array}$ \\
\hline Sample1 & $\begin{array}{l}21^{\circ} 35^{\prime} 31 \\
88^{\circ} 14^{\prime} 88\end{array}$ & 6.73 & 0.04 & 0.19 & 0.14 \\
\hline Sample2 & $\begin{array}{l}21^{\circ} 35^{\prime} 33 \\
88^{\circ} 14^{\prime} 92\end{array}$ & 6.53 & 21.9 & 4.55 & 0.59 \\
\hline Sample3 & $\begin{array}{l}21^{\circ} 35^{\prime} 33 \\
88^{\circ} 14^{\prime} 93\end{array}$ & 6.94 & 18.0 & 10.1 & 0.52 \\
\hline Sample4 & $\begin{array}{l}21^{\circ} 35^{\prime} 27 \\
88^{\circ} 15^{\prime} 03\end{array}$ & 7.1 & 35.8 & 15.0 & 1.1 \\
\hline Sample5 & $21^{\circ} 35^{\prime} 58$ & 7.54 & 25.5 & 6.21 & 1.16 \\
\hline $88^{\circ} 15^{\prime} 20$ & & & & \\
\hline
\end{tabular}

Source: Field Survey

The Patibunia Island has been divided into 5 sub-division and samples were taken from different part of the islands. From the table it is evident that among the five samples sight the $\mathrm{P}_{\mathrm{H}}$ level is high in the eastern part of the area which is 7.41 ; the moisture content is high in middle part of the area which is $25.8 \%$ and the organic matter content is high in the eastern Western part of the area which is $0.98 \%$ which clearly indicate that the zone 
with high concentration of mangrove having high moisture and organic level.

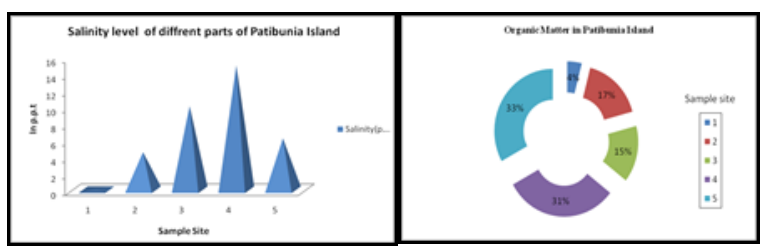

Fig. 5. Salinity level and Organic Matter of soil (Patibania Island)

The region has been divided into 12 sub-divisions and samples are taken from different parts. From the table it is evident that $\mathrm{P}_{\mathrm{H}}$ level is high in northern area which is 7.54; the moisture content is high in North -North eastern parts of area which is $35.8 \%$ and the organic matter content is also high in the Northern area which is $1.16 \%$. Along the transect mangrove species richness was also conducted and a salinity index of Patibunia also been incorporated which clearly showing that high salinity tolerating species like Tamarix galica, excocesoia agallocha were found in tidal shoal and bar (3.5-1.5 mt surface from M.S.L)

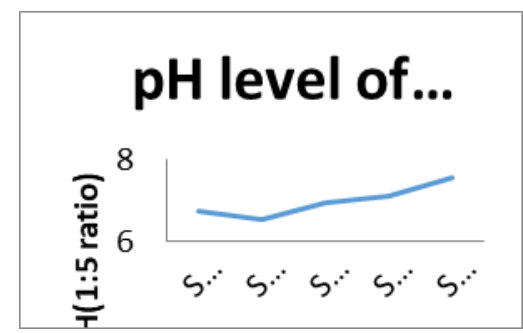

Fig. 6. pH Level of soil (Patibania Island)

Avicenia masoina, Avicenia officinalis, Acanthus ilicifoliks were present in shore fringe area (3.04 mt height). Along the inland part of the island $(72.5 \mathrm{mt})$ zone of hyper-saline patches stunted growth of mangrove scrubs like Salicornia brachiata, Avicenia alba blume, Prosoporous juliflora, Avicenia masonia are found. Next part of the island pressure nutrient rich tidal surface with high soil moisture and moderately luxuriant growth of mangrove (surface is lying over $2.5 \mathrm{mt}$ ); eg Aviceniaalba blume, Excocesoia agallocha, Ceriops tagal. This is the most attractive zone of island lying in Eastern fringe. Soil along this area have high organic matter and frequent tidal inundation at the high tides (elevation is $3.5 \mathrm{mt}$ ); eg - Suacda Moritima, Ciriops tagal, Rhizophoria, Apiculata, mangrove species richness is positively related to the soil types and age of the tidal flat.

\section{Moisture content in Patibunia island}

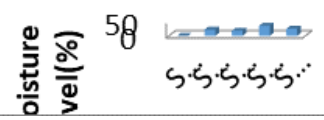

Fig. 7. Moisture Content of soil (Patibania Island)
C. Identification of hyper-saline patches and their impact on mangrove degradation

Supra tidal flats of islands and shore fringed areas of the Sundarban frequently affected by tidal inundation along with the unequal distribution of sediments in the depositional environment. Certain portion of forest floor of active tidal flat may provide evaporative environment which increases the salinity level of soil to hinder the growth of mangrove. A hyper salinity map is being prepared to show the relation between salinity level and species richness of both island These patches are formed in different forms in entire Sundarban within swampy forest. They are categorized as Salt Pond, Salt Pan, Salt flat, Saline blanks etc. Seasonal rain water storage, evaporative environment, supply of salt water during storm may accumulate in low lying areas dominated by mangrove forest and tidal inlets.

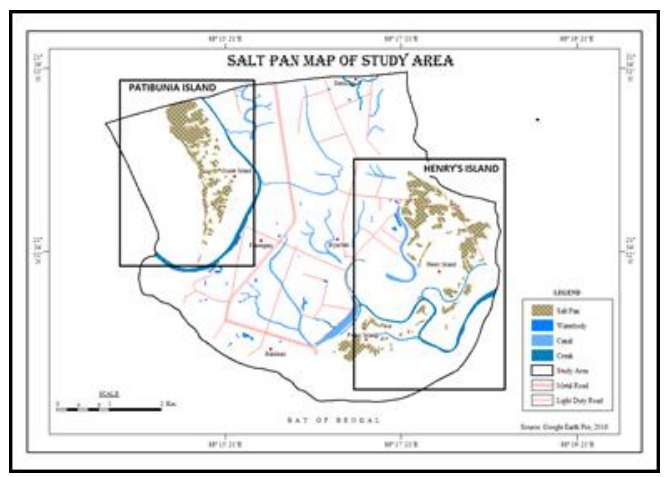

Fig. 8. Location of hypersaline tracts in the islands

Spreading of such saline patches in all over Patibunia and Henrys retard the growth of mangroves. The characteristics of the species also changes within saltpan area and adjacent region. Saltpans are common in seaward facing site of the Islands. Changes of the environment storminess of sea, prolonged evaporation in dry season help in die back process in supratidal surface of Sundarban. A salinity index Moisture index (Ray et al. 2013) of both islands have calculated by the following formula.

$$
\text { Moisture Index }=1-\left\{1 / \sqrt{ }\left(\mathrm{a}^{2}+1\right)\right\} \mathrm{x}(\mathrm{NIR}+\mathrm{a} \cdot \mathrm{Red})
$$

(Where $\mathrm{a}=$ correctional slope between NIR and Red bands.). On the basis of moisture index it is cleared that growth of mangrove are different in different spot of the islands Salinity index (Si) have been applied on the image 2016 to get the idea how and which kind of salt tolerant mangrove species can survive in such extreme climate. The calculation of the SI is following:

\section{Salinity Index $=\sqrt{ }($ BluexRed $)$}

SI showing that high saline patches areas having stunted growth of mangrove species which are reluctant to grow with 
the changing environment. Salt tolerant species are found like Salicornia brachiata, Excocesoia agallocha etc. On the other hand Patibunia island having dense vegetation concentration at the fringe area where as low concentration of mangroves are seen in the western areas due to high evaporative surface, presence of hypersaline pathaches etc. So the relationship establishes that occurance of hypersaline surface, drainage loss, extreme environment retards the growth of mangroves in the central portion and comparatively moderate species are shown in the fringe areas of islands. Salt water intrusion through creeks, pore water salinity is the major hindrance for mangrove regeneration process of Sundarban.

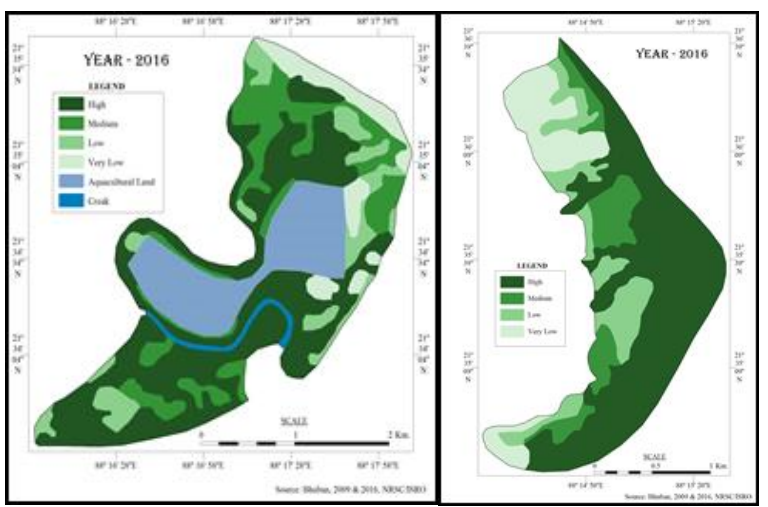

Fig. 9. Mangrove Zonation Map of Henry's and Patibania Island

\section{Major Findings}

- Hypersaline soils are the major problem of Sundarban. These are formed due to high rate of evaporation, tidal drainage loss, saltwater intrusion etc.

- Geomorphologically Sunarban is active tidal flat. Saline blanks, active tidal channel, salt marshes, sand dunes are major geomorphic unit.

- The stagnant water bodies with algal encrustation prevent the mangrove regeneration process by creating unfavorable conditions

- The sediment characteristics of the hyper saline patches indicate the low organic carbon, moderate salinity and alkaline soil. However, the organic carbon was rich in the deeper part of the soil layer.
- Mangrove degradation process increase with increasing level of salinity. The diversity of hyper saline patches varies from monsoon months to non-monsoon months depending on the availability of fresh water and rate of evaporation.

Mangroves are largely degraded due to such emerging growth of hyper saline patches in the South western part of the Sundarban.

\section{Conclusion}

Mangrove act as buffer areas of any island and reserve forest. The regeneration process of mangroves hence been hampered due to the growth of hyper saline surfaces and evaporative environment. The seaward face of any island is mainly affected by the growth of saline blanks but the level is lower in the landward side due to river floods and storm effects. Forest department has attempted to restore such degraded wetlands but understanding of mechanism for growth and extension of hyper - saline patches is essential for proper implementation of wetland restoration process.

\section{References}

[1] Heathcote R. L, Thom B. G, (1979), Natural hazards in Australia: proceedings of a symposium. Australian Academy of Science.

[2] Majumdar DD, Bera S, Ray R, Paul AK (2012) An assessment of diversities in halophytic grassland and mangrove swamp in Nayachar Island, Hugli estuary, West Bengal. in: Samanta AK,

[3] Panda $S$ (eds) Some aspects of coastal vegetation in India, including Andamans and Sundarbans. Ramnagar College, Depal, pp. 112-123.

[4] Paul A. K. (2002) Coastal geomorphology and environment. ACB Publications, Kolkata, pp. 1-585.

[5] Paul AK (2005) Tsunami: an assessment of disaster in Indian Ocean nations. ACB Publications, Kolkata, p. 89.

[6] Paul AK, Islam SM, Jana S (2014), An assessment of physiographic habitats, geomorphology and evolution of Chilika Lagoon (Odisha, India) using geospatial technology. In remote sensing and modeling. Springer International Publishing Switzerland, pp. 135-160.

[7] Raha AK, Mishra A, Bhattacharya S, Ghatak S, Pramanick P, Dey S, Sarkar I, Jha C (2014) Sea level rise and submergence of Sundarban islands: a time series study of estuarine dynamics. Int. J. Ecol Environ Sci 05:114-123.

[8] Ray R, Mondal S (2014), Remote sensing of wetland environment. LAP Lambert Academic Publishing, Saarbrücken, p. 90.

[9] Ray R, Paul AK, Basu B (2013), Application of supervised enhancement technique in monitoring the mangrove forest cover dynamics- a study on Ajmalmari reserve forest, Sundarban, West Bengal. Int J Remote Sens Geosci 2(1):16-21. 